УДК: [316.624.3: 364.63]:

004.946.5:[351.74+373.013]

https://doi.org/10.33296/2707-0255-9(17)-16

https://orcid.org/0000-0002-5288-5301*

https://orcid.org/0000-0002-9709-0879**

ПАВЛИШ ТЕТЯНА*,

кандидат педагогічних наук, доцент кафедри спеціальної техніки та інформаційних технологій Донецького юридичного інституту МВС України, м. Кривий Ріг, Україна

ХОМІЧ ЄГОР**, курсант 2-го курсу факультету №1 (Донецький юридичний інститут МВС України, м. Кривий Ріг)

\title{
РОЛЬ НАЦІОНАЛЬНОЇ ПОЛІЦІЇ УКРАЇНИ У ЗАБЕЗПЕЧЕННІ ПРОТИДІЇ КІБЕРБУЛІНГУ СЕРЕД УЧНІВ ЗАГАЛЬНООСВІТНІХ ШКІЛ
}

Анотація. Швидкий процес інформатизації суспільства робить інформацію, інформаційні, комп'ютерні, мультимедійні технології ключовим об’єктом у житті людини. На сьогодні майже кожна людина не може уявити своє життя без смартфону, комп'ютеру та будь-яких інших гаджетів, що забезпечують вихід в мережу Інтернет. Суспільні відносини, які виникають у віртуальному середовищі, можуть мати різко негативний, суспільно небезпечний характер, що зумовлює необхідність реагування правоохоронних органів. В статті наголошено на тому, що спілкування у соціальних мережах серед молоді $\epsilon$ глобальною проблемою педагогів, психологів, правоохоронців, яка охоплює широке коло негативних дій - від знущань, залякувань, цькувань

у кіберпросторі (кібербулінгу) до більш небезпечних наслідків (самогубства тощо). Акцентовано увагу на явищі кібербулінгу та протидію органами Національної поліції цьому серед учнів загальноосвітніх шкіл. Проаналізовано дослідження науковців 3 окресленої проблеми. Здійснено аналіз останніх досліджень і публікацій, щодо вирішення цієї проблеми. Викладено авторську інтерпретацію поняття «кібербулінг», як психологічний вплив однієї особистості на свідомість іншої в інформаційному просторі (умисний, систематичний, спрямований проти особистості, всупереч його волі), який вчиняється 3 використанням інформаційно-комунікаційних засобів і виражаються у формі передавання невизначеному колу інших осіб

\footnotetext{
(C) Українська інженерно-педагогічна академія

(C) ГО «Школа адаптивного управління соиіально-педагогічними системами»

(C) Павлии Т., Хоміч $\boldsymbol{C}$.
} 
повідомлень, фото-, відеоматеріалів, відеозаписів 3 метою зганьбити, принизити, залякати, образити, зацькувати їі. Визначено типи кібербулінгу. Наведено заходи профілактики явища кібербулінгу серед учнів. Ключові слова: булінг, кібербулінг, флеймінг, харасмент, обмовлення, зведення наклепів, самозванство, ошуканство, видурювання конфіденційної інформації, відчудження (остракізм, ізоляція), кіберпереслідування, хепісліппінг.

Вступ. Сьогодні в нашій державі відбувається швидкий процес інформатизації суспільства, що робить інформацію, інформаційні, комп’ютерні, мультимедійні технології ключовим об'єктом у житті людини. Майже кожна людина не може уявити своє життя без смартфону, комп’ютеру та будь-яких інших гаджетів, що забезпечують вихід в мережу Інтернету. Безумовно, в їх використанні $є$ позитивні моменти: швидкість обробки і передачі інформації, швидке вирішення професійних та освітніх задач за допомогою прикладних комп’ютерних програм, мобільних додатків у телефоні та ін.

Спостереження за розвитком комп'ютерних технологій та створеного за їх допомогою специфічного середовища - кіберпростору дає підстави говорити про розвиток нового соціального простору, який все частіше стає об’єктом юридичної науки. Стрімке проникнення віртуального простору у реальне життя кожної людини, а особливо дітей та підлітків, психіка яких знаходиться на етапі формування, з їх ще несталим світоглядом і системою цінностей, не тільки полегшило можливості комунікації та отримання практично необмеженого обсягу інформації, а й призвело до прояву агресій та інших девіантних відхилень. Суспільні відносини, які виникають у цьому віртуальному середовищі, можуть мати різко негативний, суспільно небезпечний характер, що зумовлює необхідність реагування правоохоронних органів [2, с.39].

Спілкування у соціальних мережах серед молоді $\epsilon$ глобальною проблемою педагогів, психологів, правоохоронців, яка охоплює широке коло

\footnotetext{
(C) Украӥнська інженерно-педагогічна академія

(C) ГО «Школа адаптивного управління сочіально-педагогічними системами»

(C) Павлии Т., Хоміч $\boldsymbol{~ . ~}$
} 
Електронне наукове фахове видання «Адаптивне управління: теорія і практика.

Серія «Педагогіка"

Випуск 9(17), 2020

негативних дій - від знущань, залякувань, цькувань у кіберпросторі (кібербулінгу) до більш небезпечних наслідків (самогубства тощо).огляду на це стає актуальною проблема визначення ролі Національної поліції України у забезпеченні протидії кібербулінгу серед учнів загальноосвітніх шкіл.

Аналіз останніх досліджень і публікацій. Питання кібербулінгу було Висвітлене в роботах зарубіжних (П. Агатсон, Р. Ковальські, С. Лімбер, Д. Ольвеус, В. Ортон) та вітчизняних науковців (Н. Лесько, І. Лубенець, Т. Миронюк, Л. Найдьонової, Б. Мойса, М. Фадєєвої та ін.).

Аналіз наукової літератури свідчить про те, що перед органами Національної поліції України постає важливе питання: виявити та протидіяти такому явищу серед учнів загальноосвітніх шкіл, як кібербулінг.

Метою статті с визначення ролі Національної поліції України у забезпеченні протидії кібербулінгу.

Виклад основного матеріалу. Кібербулінг - відносно нове соціальне явище, що відбувається у кіберпросторі; латентне, оскільки агресор не відчуває відповідальності за свої вчинки, адже розуміє, що все відбувається анонімно у мережі; неможливість контролювати ситуацію, тому що як тільки образливі фото або відео потрапляють у мережу, відбувається їх масове поширення різними сайтами; більшість булерів сприймають віртуальний простір несерйозно, де все відбувається «не по-справжньому», на відміну від наслідків, які є цілком реальними.

За результатами дослідження Дитячого фонду ООН (ЮНІСЕФ), в якому взяли участь більше 170 тисяч людей від 13 до 24 років із 30 країн світу, близько третини українських підлітків ставали жертвами цькування в Інтернеті.

В Україні долучилися до опитування 6791 респондент через SMS та сервіси миттєвих повідомлень і виявилося, що 29\% опитаних підлітків були жертвами онлайн-булінгу, а 16\% були змушені пропускати через це шкільні заняття [4].

\footnotetext{
(C) Украӥнська інженерно-педагогічна академія

(C) ГО «Школа адаптивного управління сочіально-педагогічними системами»

(C) Павлиш Т., Хоміч
} 
Згідно $з$ внесеними доповненнями до Закону України «Про освіту», «булінг (цькування) - діяння (дія чи бездіяльність) учасників освітнього процесу, які полягають у психологічному, фізичному, економічному, сексуальному насильстві, у тому числі із застосуванням засобів електронних комунікацій, що вчиняються стосовно малолітньої чи неповнолітньої особи та/або такою особою стосовно інших учасників освітнього процесу, внаслідок чого могла бути чи була заподіяна шкода психічному або фізичному здоров'ю потерпілого» [1].

У науковій літературі існує широкий спектр тлумачень поняття кібербулінгу, а саме: «кібербулінг - це жорстокі дії з метою дошкулити, нашкодити, принизити дитину, в яких використовуються інформаційнокомунікаційні засоби: мобільні телефони, електронна пошта, соціальні мережі тощо» [6, с.17-18]; «систематичні умисні дії з боку особи або групи осіб (частіше підлітків) із використанням інформаційно-комунікаційних засобів, спрямовані проти іншої особи (осіб), що характеризуються створенням ворожої, принизливої, образливої обстановки й метою або наслідком яких $€$ залякування, порушення права на безпечне навчання, повагу, честь, гідність, майно, здоров'я і життя, обмеження свободи волевиявлення особи (осіб) тощо» [4, с.179]; «агресивна поведінка певної особи, найчастіше підлітка, яка здійснюється проти конкретної дитини (жертви) засобами електронної комунікації (Інтернет, мобільні телефони, соціальні мережі)» [7, с. 24].

Підсумовуючи вище зазначене, розуміємо кібербулінг, як психологічний вплив однієї особистості на свідомість іншої в інформаційному просторі (умисний, систематичний, спрямований проти особистості, всупереч його волі), який вчиняється 3 використанням інформаційно-комунікаційних засобів і виражаються у формі передавання невизначеному колу інших осіб повідомлень, фото-, відеоматеріалів, відеозаписів з метою зганьбити, принизити, залякати, образити, зацькувати ii.

\footnotetext{
(C) Украӥнська інженерно-педагогічна академія

(C) ГО «Школа адаптивного управління сочіально-педагогічними системами»

(C) Павлиш Т., Хоміч
} 
Електронне наукове фахове видання «Адаптивне управління: теорія і практика.

Як зауважує Л. Найдьонова, «діти часто не розповідають батькам про такі негаразди через страх батьківської заборони використання потрібних їм засобів зв’язку, і тому залишаються без необхідної підтримки і допомоги. Небезпечність кібербулінга, у порівнянні зі звичайним булінгом, полягає у важкості його виявлення, анонімності осіб, які здійснюють кібербулінг, а також найголовніше - кібербулінг не передбачає наявність географічних та часових меж такого впливу, особливо якщо особи постійно перебувають на просторах Інтернету, у соціальних мережах, звичайний булінг же обмежується певним місцезнаходженням дитини, соціальним середовищем та часовими межами, перш за все, під час перебуванні у школі, класі, гуртку і т.д.» $[6$, с. $17-18]$.

На думку Д. Ольвеуса, «найчастіше жертвами булінгу стають діти, які: мають підвищений або високий рівень тривожності, нещасні, невпевнені в собі, із заниженим або низьким рівнем самооцінки; не мають близького друга серед однолітків, віддають перевагу спілкуванню із старшими дітьми або 3 дорослими; сором'язливі, лякливі, чутливі; схильні до меланхолії; фізично слабші діти, у порівнянні з ровесниками. Також жертвами булінгу можуть стати діти, які: пасивно очікують насильства від агресора; самотні; мають негативний досвід життя; походять із соціально-неблагополучних сімей; зазнають фізичного насильства в сім’ї; не вірять, що їх можуть захистити вчителі; замовчують факти насильства та цькування; не вважають себе значущими; прийняли насильство як норму» [9].

Як зазначають О. Міхєєва, М. Корнієнко, «кібербулінг являється формою психологічного насильства. Найчастіше жертвами саме кібербулінгу стають підлітки, що позбавлені батьківського піклування та уваги, не мають емоційного зв'язку із батьками; підлітки, що зазнають жорстокості від батьків, вороже сприймають світ і у реальному житті часто стають жертвами насильства самі проявляють насильницькі дії у сторону слабших від них; підлітки, що виховуються в умовах тиранії з боку батьків, і перебувають у

\footnotetext{
(C) Украӥнська інженерно-педагогічна академія

(C) ГО «Школа адаптивного управління сочіально-педагогічними системами»

(C) Павлиш Т., Хоміч
} 
Електронне наукове фахове видання «Адаптивне управління: теорія і практика.

Серія «Педагогіка"

Випуск 9(17), 2020

постійній ситуації підкорення волі і неможливості виразити свою думку; підлітки, що мають психофізичні особливості (різні форми розумової відсталості, психопатії, заяча губа, вовча паща та ін.); підлітки 3 сімей 3 низьким соціальним статусом» [5, с.249].

Американські вчені Р. Ковальскі, С.Лімбер, П.Агатстон виділили вісім типів поведінки, характерних для кібербулінгу: перепалки, або флеймінг обмін короткими, гнівними, запальними репліками між двома чи більше учасниками за допомогою комунікаційних технологій (в чатах, на форумах); нападки, або харасмент - це використання повторюваних образливих повідомлень, спрямованих на жертву (наприклад, постійні погрозливі дзвінки, маса СМС-повідомлень на мобільний телефон) з перевантаженням персональних каналів комунікації; обмовлення, зведення наклепів розповсюдження принизливої неправдивої інформації 3 використанням комп'ютерних технологій (текстові повідомлення, фото, відео, які змальовують жертву в образливій формі, жертвами можуть стати не тільки окремі особи, але група дітей (наприклад, «хто є хто» в класі, школі); самозванство, втілення в певну особу - агресор позиціонує себе жертвою, використовуючи їі пароль доступу до аккаунту в соціальних мережах, блозі, пошті, системі миттєвих повідомлень тощо, а потім здійснює негативну комунікацію. Коли з адреси жертви без іiі відому відправляються ганебні провокаційні листи, виникає «хвиля зворотних зв'язків», в результаті якої розгублена жертва неочікувано отримує гнівні відповіді; ошуканство, видурювання конфіденщійної інформаџіï та ї̈ розповсюдження - отримання персональної інформації (текстів, фото, відео) і пї передача іншим поштою або в публічну зону Інтернету; відчуження (остракізм, ізоляція). Бажання бути включеним у групу є мотивацією багатьох вчинків дитини, i саме тому виключення з групи однолітків сприймається як соціальна «смерть». Онлайнвідчуження можливе 3 різних в будь-якому віртуальному дитячому середовищі, де використовується захист паролями, формується список

\footnotetext{
(C) Украӥнська інженерно-педагогічна академія

(C) ГО «Школа адаптивного управління сочіально-педагогічними системами»

(C) Павлиш Т., Хоміч
} 
Електронне наукове фахове видання «Адаптивне управління: теорія і практика.

небажаної пошти, список друзів. Кіберостракізм проявляється також через відсутність швидкої відповіді на миттєві повідомлення чи електронні листи; кіберпереслідування - приховане вистежування через Інтернет та переслідування необережних чи вибраних з певною метою користувачів для організації злочинних дій (нападу, побиття,

згвалтування); хепіслеппінг - дуже розповсюджений вид кібербулінгу, який уявляє собою розміщення відеороликів в Інтернеті, де їх можуть переглядати тисячі користувачів без жодної згоди жертви. Інша форма хепіслепінгу - це передавання сюжетів через мобільні телефони [8].

I. Лубенець, досліджуючи явище кібербулінгу, виділяє такі його форми: персоніфікований, яка передбачає адресну розсилку інформації жертві; не персоніфікований, що полягає у розповсюдженні інформації жертві й поширенні іï в публічному інформаційному просторі для невизначеного кола осіб, створюючи навколо жертви в референтних соціальних групах (клас, двір, школа) негативну обстановку неповаги, приниження, засудження, ізоляції тощо; відкритий, прямий кібербулінг розсилка повідомлень, листів, відео, фотографій образливого, погрожуючого характеру; розповсюдження особистої інформації (правдивої або неправдивої), яка дискредитує жертву; зйомка бійок, знущань за допомогою сучасних гаджетів із подальшою їх демонстрацією; латентний кібербулінг це прихована агресія, за якої поведінка кібербулера замаскована під звичайну бесіду щодо обміну думок, дискусію тощо, тобто вона не позиціонує себе як агресивну. Знаряддям образ є сарказм, іронія, про вокативна поведінка тощо. Метою такої поведінки є образи, дошкуляння, провокація конфлікту, здобуття інформації особистого характеру з подальшим іiі використанням у хуліганських або злочинних цілях тощо [4, с. 179].

На сьогодні чинне законодавство не досконале, тому вести статистику та юридично кваліфікувати вияви кібернасильства дуже важко. Обліковуються лише випадки, коли такі дії призвели до серйозних наслідків,

\footnotetext{
(C) Украӥнська інженерно-педагогічна академія

(C) ГО «Школа адаптивного управління сочіально-педагогічними системами»

(C) Павлиш Т., Хоміч
} 
Електронне наукове фахове видання «Адаптивне управління: теорія і практика.

відповідальність за які передбачена Кримінальним Кодексом України або Кодексом законів про адміністративні правопорушення України [4, с.181].

Слід зауважити, що згідно чинного законодавства «будь-яке насильство над дитиною та іiі експлуатація переслідуються за законом» - так звучить норма ч. 2 ст. 52 Конституції України. На реалізацію цієї конституційної норми 19 січня 2019 року набув чинності Закон України «Про внесення змін до законодавчих актів України щодо протидії булінгу (цькуванню)» від 18.12.2018 № 2657 - VIII [1]. Ним визначено поняття булінгу, шляхи протидії цьому явищу, захисту прав дітей та інших осіб, які працюють у закладі освіти, а також встановлено адміністративну відповідальність за булінг, приховування випадків булінгу педагогами чи керівниками закладу освіти. За вказаним законом було доповнено Кодекс України про адміністративні правопорушення новою статтею 173-4 «Булінг (цькування) учасника освітнього процесу». Згідно з цим доповненням за булінг настає адміністративна відповідальність у вигляді штрафу від 50 мндг (850 грн) чи громадських робіт на строк від 20 год. Відповідальність посилюється, якщо булінг вчиняється групою осіб або повторно протягом року після накладення адміністративного стягнення. Якщо булінг вчиняли малолітні діти (особи у віці до 14 років) чи неповнолітні діти у віці від 14 до 16 років, то адміністративну відповідальність у вигляді штрафу чи громадських робіт несуть їхні батьки чи особи, які їх замінюють. Неповідомлення керівниками закладів освіти органів поліції про випадки булінгу у закладі тягне накладення штрафу від 50 до 100 нмдг $(850-1700$ грн) або виправні роботи на строк до 1-го місяця з відрахуванням до 20\% заробітку.

Для доведення факту насильства щодо дітей в Інтернеті потерпілі як доказ подають скріншоти (знімки екрана, які відображають інформацію, що стала причиною конфлікту, в тому вигляді, в якому вона є поширеною в Інтернеті). В чинному законодавстві слід прописати процедуру

\footnotetext{
(C) Украӥнська інженерно-педагогічна академія

(C) ГО «Школа адаптивного управління сочіально-педагогічними системами»

(C) Павлиш Т., Хоміч
} 
Електронне наукове фахове видання «Адаптивне управління: теорія і практика.

розслідування правоохоронними органами факту кібербулінгу.

Таким чином, законодавство щодо протидії булінгу і кібербулінгу потребує доопрацювань і роз'яснень.

Питання кібербулінгу дуже актуальне на сьогоднішній день як для педагогів, психологів так і представників органів Національної поліції, оскільки краще прояви кібербулінгу попереджувати, ніж спостерігати за їх наслідками. Тільки при спільній профілактичній роботі з булерами і жертвами кібербулінгу батьків, школи і поліції можливо подолати це явище. Досягається це за проведення з дітьми виховних годин, роз'яснювальних бесід представниками ювенальної превенції .

Висновки 3 наданого дослідження $\mathbf{i}$ перспективи подальших розвідок в окресленому напрямі. Отже, кібербулінг є відносно новим поняттям у педагогічній, психологічній, юридичній літературі. Його формування - наслідок поширення у соціальному житті ролі комунікаційних технологій: телефонного зв'язку, Інтернету та соціальних мереж. Перед представниками органів Національної поліції постає питання належно оцінити шкоду, нанесену дитині через соціальні мережі та розробити заходи профілактики кібербулінгу: проведення роз'яснювальних бесід та підготовка інфографіки, презентаційних матеріалів, буклетів $з$ даного питання.

Окреслене питання щодо протидії кібербулінгу може бути вирішене тільки у співпраці загальноосвітніх шкіл, Національної поліції та батьків.

\section{СПИСОК ВИКОРИСТАНИХ ДЖЕРЕЛ}

1. Булінг в закладах освіти: юридичні аспекти. URL: http://lawyerblog.odb.poltava.ua/2019/02/05/булінг-в-закладах-освітиюридичні-асп/

2. Давидюк В.М. Інтернет, як соціальне середовище роботи 3 конфідентами. Актуальні питання протидії кіберзлочинності та торгівлі людьми: збірник матеріалів Всеукр. наук.-практ. конф. (23 листоп. 2018 р., м. Харків). МВС України, Харків. нац. ун-т внутр. справ; Координатор проектів ОБСС в Україні. Харків: ХНУВС, 2018. - 436 с.

3. Дослідження ЮНICЕФ про кібербулінг. URL: https://pon.org.ua/novyny/7317-dosldzhennya-yunsef-pro-kberbulng.html

\footnotetext{
(C) Украӥнська інженерно-педагогічна академія

(C) ГО «Школа адаптивного управління сочіально-педагогічними системами»

(C) Павлии Т., Хоміч $\boldsymbol{~ . ~}$
} 
4. Зупинимо поширення булінгу серед студентів! URL: http://khntusg.com.ua/uk/node/745

5. Лубенець Ірина. Кібернасильство (кібербулінг) серед учнів загальноосвітніх навчальних закладів. Национальный юридический журнал: теория и практика. 2016. № 3. С. 178-182.

6. Міхєєва О.Ю., Корнієнко М.М. Кібербулінг як соціально-педагогічна проблема. Young Scientist. № 11 (63), 2018. URL: http://molodyvcheny.in.ua/files/journal/2018/11/60.pdf

7. Найдьонова Л.А. Кібербулінг або агресія в інтернеті: способи розпізнання і захист дитини. Методичні рекомендації . Серія: На допомогу вчителю. Вип. 4. К., 2011. 34 с.

8. Фадєєва М. В. Структура психологічної готовності вчителя до надання психологічної допомоги дитині - жертві кібербулінгу. Проблеми сучасної педагогічної освіти. Сер.: Педагогіка і психологія: зб. ст. Ялта : РВВ КГУ, 2013. Вип. 39, ч. 1. С. 21-27.

9. Kowalski R. Cyber bullying: bullying in the digital age / R.Kowalski, S.Limber, P.Agatston. Oxford: Blackwell Publishing Ltd, 2008. 218 p.

10. Olweus D. Bullying at school. Blackwell Publ. 1993. 215 p. URL: https://books.google.com.ua/

\section{REFERENSES}

1. Buling $\mathrm{v}$ zakladax osvity: yurydychni aspekty. URL: http://lawyerblog.odb.poltava.ua/2019/02/05/buling-v-zakladax-osvity`yury`dy`chni-asp/

2. Davydyuk V.M. Internet, yak socialne seredovyshhe roboty $\mathrm{z}$ konfidentamy. Aktualni pytannya protydiyi kiberzlochynnosti ta torgivli lyudmy: zbirnyk materialiv Vseukr. nauk.-prakt. konf. (23 ly`stop. 2018 r., m. Xarkiv). MVS Ukrayiny, Xarkiv. nacz. un-t vnutr. sprav; Koordynator proektiv OBSYe v Ukrayini. Xarkiv: XNUVS, 2018. - 436 s.

3. Doslidzhennya YuNISEF pro kiberbuling. URL: https://pon.org.ua/novyny/7317-dosldzhennya-yunsef-pro-kberbulng.html

4. Zupynemo poshyrennya bulingu sered studentiv! URL: http://khntusg.com.ua/uk/node/745

5. Lubenecz Iryna. Kibernasylstvo (kiberbuling) sered uchniv zagalnoosvitnix navchalnyx zakladiv. Nacyonalnыj yurydycheskyj zhurnal: teoryya y praktyka. 2016. S. 178-182.

6. Mixyeyeva O.Yu., Korniyenko M.M. Kiberbuling yak socialnopedagogichna problema. Young Scientist. 11(63), 2018. URL:

http://molodyvcheny.in.ua/files/journal/2018/11/60.pdf

7. Najdonova L.A. Kiberbuling abo agresiya $\mathrm{v}$ interneti: sposoby rozpiznannya i zaxyst dytyny. Metodychni rekomendaciyi . Seriya: Na dopomogu vchytelyu. Vyp. 4. K., 2011.34 s.

8. Fadyeyeva M. V. Struktura psyxologichnoyi gotovnosti vchytelya do nadannya psyxologichnoyi dopomogy dytyni - zhertvi kiberbulingu. Problemy

\footnotetext{
(C) Украӥнська інженерно-педагогічна академія

(C) ГО «Школа адаптивного управління сочіально-педагогічними системами»

(C) Павлиш Т., Хоміч $\boldsymbol{C}$.
} 
suchasnoyi pedagogichnoyi osvity. Ser.: Pedagogika i psyxologiya: zb. st. Yalta : RVV KGU, 2013. Vyp. 39, ch. 1. S. 21-27.

9. Kowalski R. Cyber bullying: bullying in the digital age / R.Kowalski, S.Limber, P.Agatston. Oxford: Blackwell Publishing Ltd, 2008. 218 p.

10. Olweus D. Bullying at school. Blackwell Publ. 1993. 215 p. URL: https://books.google.com.ua/

\title{
ПАВЛЫШ ТАТЬЯНА
}

кандидат педагогических наук, доцент кафедры специальной техники и информационных технологий Донецкого юридического института МВД Украины, г. Кривой Рог, Украина

\section{ХОМИЧ ЕГОР,} курсант 1-го курса факультета №1 (Донецкий юридический институт

МВД Украины, г. Кривой Рог)

\section{РОЛЬ НАЦИОНАЛЬНОЙ ПОЛИЦИИ УКРАИНЫ В ОБЕСПЕЧЕНИИ ПРОТИВОДЕЙСТВИЯ КИБЕРБУЛЛИНГА СРЕДИ УЧАЩИХСЯ ОБЩЕОБРАЗОВАТЕЛЬНЫХ ШКОЛ}

\begin{abstract}
Аннотация. Быстрый процесс информатизации общества делает информацию, информационные, компьютерные, мультимедийные технологии ключевым объектом в жизни человека. Сегодня почти каждый человек не может представить свою жизнь без смартфона, компьютера и любых других гаджетов, которые обеспечивают выход в сеть Интернет. Общественные отношения, возникающие в виртуальной среде, могут иметь резко негативный, общественно опасный характер, что вызывает необходимость реагирования правоохранительных органов. В статье отмечено, что общение в социальных сетях среди молодежи является глобальной проблемой педагогов, психологов, правоохранителей, которая охватывает широкий круг негативных действий - от издевательств, запугивания, травли в киберпространстве (кибербуллинга) до более опасных последствий (самоубийства и т.д.). Акцентировано внимание на явлении кибербуллинга и противодействие органами Национальной полиции этому среди учащихся общеобразовательных школ. Проанализированы исследования ученых из обозначенной проблемы. Осуществлен анализ последних исследований и публикаций, в которых начато решение этой проблемы. Изложена авторская интерпретация понятия «кибербуллинг», как психологическое воздействие одной личности на сознание другого в информационном пространстве (умышленное, систематическое, направленное против личности, против его воли), которое совершается с использованием информационно-коммуникационных средств и выражается в
\end{abstract}

\footnotetext{
(C) Украӥнська інженерно-педагогічна академія

(C) ГО «Школа адаптивного управління сочіально-педагогічними системами»

(C) Павлии Т., Хоміч $\boldsymbol{~ . ~}$
} 
форме передачи неопределенному кругу других лиц сообщений, фото-, видеоматериалов, видеозаписей с целью опорочить, унизить, запугать, оскорбить, затравить ее. Определены типы кибербуллинга. Предложены мероприятия по профилактике явления кибербуллинга среди учеников.

\title{
PAVLYSH TETIANA
}

PhD of Pedagogical Sciences, Donetsk

Law Institute of the Ministry of Internal

Affairs of Ukraine, Kryvyi Rih, Ukraine

\section{EGOR HOMICH}

1 st year cadet of the faculty №1

Donetsk Law Institute of the Ministry of Internal Affairs of Ukraine, Kryvyi Rih, Ukraine

\section{THE ROLE OF THE NATIONAL POLICE OF UKRAINE IN PROVIDING COUNTERFEITING CYBERBULNING AMONG STUDENTS OF SECONDARY SCHOOLS}

\begin{abstract}
The rapid process of informatization of society makes information, information, computer, multimedia technologies a key object in human life. Today, almost everyone cannot imagine their lives without a smartphone, computer and any other gadgets that provide access to the Internet. Public relations that arise in a virtual environment can be sharply negative, socially dangerous, which necessitates the response of law enforcement agencies. The article emphasizes that communication on social networks among young people is a global problem of teachers, psychologists, law enforcement, which covers a wide range of negative actions - from bullying, intimidation, harassment in cyberspace (cyberbullying) to more dangerous consequences (suicide, etc.). Emphasis is placed on the phenomenon of cyberbullying and the opposition of the National Police to this among secondary school students. The research of scientists on the outlined problem is analyzed. An analysis of recent research and publications in which the solution to this problem has been initiated. The author's interpretation of the concept of "cyberbullying" as a psychological influence of one person on the consciousness of another in the information space (intentional, systematic, directed against the person, against his will), which is done using information and communication tools and expressed in the form of transmission to others messages, photos, videos, videos in order to disgrace, humiliate, intimidate, insult, harass her. Types of cyberbullying are identified. Proposed measures to prevent cyberbullying among pupils.
\end{abstract}

Key words: bullying, cyberbullying, flaming, harassment, slander, defamation, impersonation, fraud, extortion of confidential information, alienation (ostracism, isolation), cyberbullying, happy slipping.

\footnotetext{
(C) Украӥнська інженерно-педагогічна академія

(C) ГО «Школа адаптивного управління соиіально-педагогічними системами»

(C) Павлиш Т., Хоміч $\boldsymbol{C}$.
} 